41 Chen, P.S. and Balmer, J. (1989) J. Insect Physiol. 35, 759-764

42 Kasule, F.K. (1986) Zool. J. Linn. Soc. 88, 191-199

43 Chapman, T., Liddle, L.F., Kalb, J.M., Wolfner, M.F. and Partridge, L. (1995) Nature 373, 241-244
44 Andersson, M. (1994) Sexual Selection, Princeton University Press

45 Crabtree, C. (1911) Anat. Rec. 79, 395-113

46 Milligan, S.R. (1980) Symp. Zool. Soc. London $45,251-275$

47 Milligan, S.R. (1982) Oxf. Rev. Reprod. Biol. 4, $1-46$
48 Albone, E.S. (1984) Mammalian Semiochemistry, Wiley

49 Lyons, S.A. and Getz, L.L. (1993) Behav. Proc 29, 191-200

50 Bronson, F.H. (1979) Q. Rev. Biol. 54, 265-299

51 Lewis, C.T. and Pollock, J.N. (1975) J. Entomol. (A) 49, 137-147

\title{
The early role of nitric oxide in evolution
}

\section{Martin Feelisch \\ John F. Martin}

\begin{abstract}
Nitric oxide (NO), which today serves many different purposes in regulating complex cellular functions, must have played a crucial role in the early stages of the evolution of life. The formation of NO may have been a critical defence mechanism for primitive microorganisms at a time when life faced the problem of rising atmospheric levels of ozone $\left(\mathrm{O}_{3}\right)$ formed upon photolysis of oxygen $\left(\mathrm{O}_{2}\right)$, which occurred shortly after the development of respiration in cyanobacteria. The production of NO by organisms would have allowed neutralization of toxic $\mathrm{O}_{3}$ by chemical reaction outside the cell, thus acting as a protective mechanism against oxidative destruction, allowing evolutionary advantage. Later, NO production might have allowed the control of reactive $\mathrm{O}_{2}$ species within cells before the development of specific electron-accepting enzymes. The pathway of NO formation was then consequently developed further to serve other useful functions. Although mammalian cells produce NO from L-arginine, the origin of this ability might have arisen from the essential process of either nitrification or denitrification in prokaryotic cells.
\end{abstract}

Martin Feelisch is at the Dept of Nitric Oxide Research, Schwarz Pharma AG, Alfred Nobel Str. 10, D-40789 Monheim, Germany

John Martin is at the Dept of Medicine, King's College School of Medicine and Dentistry, Denmark Hill, London, UK SE5 9PJ.

$\mathrm{N}^{\mathrm{in}}$ ric oxide (NO) possesses an unusually large repertoire of physiological and pathophysiological functions in the mammalian cardiovascular and nervous systems as well as in immunological defence mechanisms (see Table 1). It is synthesized from the terminal guanidinonitrogen of the amino acid, L-arginine, by a family of enzymes, the NO-synthases (NOSs). This biochemical route was named the L-arginine-NO pathway ${ }^{1-3}$. Recently, it has been demonstrated that NO is synthesized from L-arginine by haemocytes, the multicompetent cells in the haemolymph of an arthropod - the American horseshoe crab (Limulus polyphemus) - and that the endogenous formation of NO regulates the functional activity of these cells ${ }^{4}$. Horseshoe crabs have changed little over 500 million years of evolution ${ }^{5}$. Furthermore, NO has been shown to be produced and used as a bacteriocidal agent by invertebrate immunocytes ${ }^{6}$. Histochemical evidence confirmed the existence of NOS in the nervous, neuroendocrine and intestinal vascular systems of invertebrates ${ }^{7-10}$, and in the gastrointestinal and respiratory systems of amphibia and reptilia ${ }^{11,12}$. The bug Rhodnius prolixus has even evolved the use of $\mathrm{NO}$ as an agent outside itself 13 : its salivary gland contains a carrier protein that allows injection of NO into the prey's vascular system, causing blood vessel relaxation at the site of the bite, thus allowing more efficient blood sucking ${ }^{14}$. NOS has been purified from an acellular slime mould, Physarum polycephalum, and a link between NOS activity and mitosis has been suggested ${ }^{15}$. It has been shown that NO is involved in the feeding response of $\mathrm{Hydra}$ - the most primitive olfactory-like behavioural phenomenon present in multicellular organisms ${ }^{16}$

Hence, the pathway of $\mathrm{NO}$ formation may be one of the oldest bioregulatory systems controlling human and animal physiology. The question arises why such a simple molecule should serve so many purposes in regulating diverse and complex cellular functions. What was the function of $\mathrm{NO}$ in the evolutionary early stages of life?
The evolution of the palaeoatmosphere and life on Earth

About 60 years ago, Oparin ${ }^{17}$ and Haldane ${ }^{18}$ independently proposed that life on Earth developed from a dilute 'primordial soup' consisting of a great variety of complex organic molecules that, over geological time, became living systems. The progenitors of cells are assumed to have been coacervates and microspheres of proteinoids, or strands of nucleic acid, capable of building complex, self-organized protein-nucleic acid systems ${ }^{19}$. The evolution of life is thought to be intimately related to the composition and evolution of the early Earth's atmosphere. It is generally believed that the atmosphere as well as the oceans were formed by the volcanic outgassing of volatiles that were originally trapped in our planet's interior during its formation ${ }^{20}$. More recently, it has been suggested that the Earth received a significant portion of the constituents present in the atmospheric/biospheric system from cometary volatile influx ${ }^{21}$ and that extraterrestrial impactors may have supplied the organic material necessary for the origin of terrestrial life ${ }^{22}$.

The developing prebiological palaeoatmosphere is believed to have been composed mainly of nitrogen $\left(\mathrm{N}_{2}\right)$, carbon dioxide $\left(\mathrm{CO}_{2}\right)$, water vapour $\left(\mathrm{H}_{2} \mathrm{O}\right)$ and reduced species such as methane $\left(\mathrm{CH}_{4}\right)$ and ammonia $\left(\mathrm{NH}_{3}\right)$, with only traces of oxygen $\left(\mathrm{O}_{2}\right)$, carbon monoxide $(\mathrm{CO})$ and nitrogen oxides $\left(\mathrm{NO}_{\mathrm{x}}\right)$. While there is general agreement that this prebiological palaeoatmosphere was reducing in nature, there is uncertainty as to whether it was strongly or mildly reducing ${ }^{23}$. In any case, temperature on Earth at that time was too high for water to exist in liquid form, making it impossible for life to arise. In the course of several hundred million years, so much energy escaped into space that temperature on Earth decreased to a level allowing the water vapour to condense and oceans to be formed.

Microfossils and stromatolitic structures in ancient sediments indicate that life first started to evolve about 3.5 billion years $\mathrm{ago}^{24}$. The first primitive forms of cells are thought to have been anaerobic heterotrophs that met their energy demands by exploiting reduced organic molecules formed by abiotic natural processes 
Table 1. Biological activities of nitric oxide ${ }^{a}$

\begin{tabular}{|c|c|c|}
\hline Tissue/Organ & Physiological actions & Pathophysiological actions \\
\hline Vascular endothelium & $\begin{array}{l}\text { Maintains vasodilator tone; inhibits smooth-muscle cell migration } \\
\text { and proliferation; inhibits blood cell-vessel wall interactions }\end{array}$ & $\begin{array}{l}\text { Mediates hypotension, hyposensitivity to vasoconstrictors and } \\
\text { vascular leakage in septic shock; contributes to inflammatory } \\
\text { responses and reperfusion injury }\end{array}$ \\
\hline Blood cells & $\begin{array}{l}\text { Prevents aggregation and adhesion of platelets and white cells; } \\
\text { mediates cytostatic and cytotoxic activity of macrophages for } \\
\text { antimicrobial and antitumour defence }\end{array}$ & $\begin{array}{l}\text { Contributes to allograft rejection, graft versus host disease } \\
\text { and tissue damage in inflammation }\end{array}$ \\
\hline Heart & Maintains coronary perfusion; regulates cardiac contractility & Contributes to cardiac dysfunction in sepsis \\
\hline Lung & $\begin{array}{l}\text { Maintains ventilation/perfusion ratios; regulates bronchociliar } \\
\text { motility and mucus secretion }\end{array}$ & May contribute to inflammatory response in asthma \\
\hline Pancreas & Modulates endocrine secretion & Destruction of islets of Langerhans \\
\hline Kidney & Regulates glomerular perfusion and renin secretion & May contribute to kidney failure \\
\hline intestinal system & $\begin{array}{l}\text { Modulates peristaisis and exocrine secretion; contributes to } \\
\text { protection of mucosa }\end{array}$ & Contributes to mucosal damage in inflammatory processes \\
\hline $\begin{array}{l}\text { Central and peripheral } \\
\text { nervous system }\end{array}$ & $\begin{array}{l}\text { Modulates and mediates cell-to-cell communication; regulates } \\
\text { visual transduction, neuro-endocrine secretion, cerebral blood } \\
\text { flow, synaptic plasticity, memory, feeding behaviour and olfaction; } \\
\text { mediates penile erection }\end{array}$ & $\begin{array}{l}\text { Contributes to neurotoxicity and hyperalgesia; possible } \\
\text { involvement in convulsion, stroke and migraine }\end{array}$ \\
\hline
\end{tabular}

over the course of several hundred million years. The evolution of metabolic capabilities overcame deficiencies in the abiotic supply of particular organic compounds ${ }^{25}$. Since these sources were replenished much more slowly than the rapidly spreading cells consumed them, life was impeded by the depletion of fermentable organic material, forcing evolution to find a way to make use of alternative energy sources. Life may have disappeared and evolved several times until a pioneering cell found a solution to overcome the energy crisis by making use of solar energy to build up new organic molecules. Photosynthetic bacteria appeared that still relied on external sources for hydrogen $\left(\mathrm{H}_{2}\right)$ until some mutants 'learned' to use abundant $\mathrm{H}_{2} \mathrm{O}$ as an electron donor. Some of these new bacteria were capable of using $\mathrm{CO}_{2}$ to produce carbohydrates with the aid of parts of the electron-transport chain developed earlier.

\section{The origin and evolution of oxygen and ozone}

Molecular $\mathrm{O}_{2}$ only occurred in traces in the prebiological palaeoatmosphere and is considered to have been formed mainly by photodissociation of water vapour in the upper atmosphere followed by escape of $\mathrm{H}_{2}$ into space ${ }^{26}$. The rapid appearance of autotrophic cyanobacteria with complex photosynthetic electron-transport chains, however, caused $\mathrm{O}_{2}$ to be produced in large amounts. The potentially toxic 'waste material', $\mathrm{O}_{2}$, with the depletion of dissolved reduced iron $\left(\mathrm{Fe}^{2+}\right)$ salts and sulphides in the primaeval ocean (which first acted as natural antioxidants and as a sink for $\mathrm{O}_{2}$, and, furthermore, may have allowed the cyanobacteria to elaborate a defence mechanism against their own $\mathrm{O}_{2}$ production), gradually accumulated in the water and the atmosphere, resulting in the transition from reducing to oxidizing conditions. Recently discovered, early Archean microfossil records show that cyanobacterial $\mathrm{O}_{2}$-producing photosynthesizers were already extant and morphologically diverse as early as 3465 million years ago ${ }^{27}$. Having solved the energetic problem of an efficient aerobic metabolism, organisms were thus faced with the problem of requiring a cellular defence system against oxidative stress. Mutants of some cyanobacteria with enzymes capable of protecting against aggressive $\mathrm{O}_{2}$-derived species developed some of these defence systems even further to gain energy from the $\mathrm{O}_{2}$ molecule - a proccss we call respiration.

As atmospheric levels of $\mathrm{O}_{2}$ increased, so did levels of ozone $\left(\mathrm{O}_{3}\right)$ as a result of photolysis of $\mathrm{O}_{2}$ (Ref. 23). Today, $\mathrm{O}_{3}$ is considered a key atmospheric gas in controlling the environment that led to the origin and evolution of life on our planet. The impact of rising atmospheric levels of $\mathrm{O}_{3}$ was two-fold: on the one hand, $\mathrm{O}_{3}$ exerts a protective effect by virtue of its strong absorption in the range between 200 and $300 \mathrm{~nm}$, thus largely reducing the lethal solar UV flux reaching the Earth's surface and allow- ing the evolution of terrestrial life ${ }^{26,28}$. On the other hand, $\mathrm{O}_{3}$ is an aggressive oxidant causing destruction of biological membranes and organic molecules in general29. Many varieties of plant life are extensively damaged when exposed to $\mathrm{O}_{3}$ concentrations only 2-3 times greater than the present average ambient concentrations. Photochemical model calculations revealed that surface and tropospheric $\mathrm{O}_{3}$ densities of the palaeoatmosphere exceeded those of the present atmosphere by about a factor of ten ${ }^{30}$. Therefore, with increasing formation of $\mathrm{O}_{2}$ in the palaeoatmosphere, the level of $\mathrm{O}_{3}$ is likely quickly to have approached concentrations that were toxic for living organisms. Thus, a way to counteract effectively these adverse effects of $\mathrm{O}_{3}$ would have been essential for living systems to survive.

NO is known to react rapidly with $\mathrm{O}_{3}$ and to contribute largely to the destruction of $\mathrm{O}_{3}$ in the present stratosphere $\mathrm{e}^{21,33}$. Therefore, it is conceivable that, under these conditions, the ability of some mutants producing $\mathrm{NO}$ and delivering it to the extracellular environment must have been ideally suited to neutralize excess $\mathrm{O}_{3}$ by chemical reaction outside the cell. This assumption is in agreement with the recent observation that the decline in $\mathrm{O}_{3}$ concentrations near the ground appears to result not only from consumption by the vegetation and deposition, respectively, but also from chemical reaction with emanations of NO from denitrifying bacteria in the soil ${ }^{32}$. In addition to these environmental 
changes, an increased formation of reactive $\mathrm{O}_{2}$ species, such as superoxide anions $\left(\mathrm{O}_{2}^{-}\right)$, hydrogen peroxide $\left(\mathrm{H}_{2} \mathrm{O}_{2}\right)$ and hydroxyl radicals $(\cdot \mathrm{OH})$ may have occurred within living cells as a result of insufficient electron cycling. Before specific enzymes such as superoxide dismutase, catalase and peroxidase were developed, those cells capable of generating $\mathrm{NO}$ are again likely to have proven more resistant to these new living conditions than cells lacking such an activity. Later on, and possibly still today, NO might have served as a defence mechanism against an excess formation of reactive $\mathrm{O}_{2}$ species by virtue of its high reactivity towards $\mathrm{O}_{2}^{-}$(Ref. 33 ). The biological consequences of such an evolutionary step must have been farreaching. As a consequence, those organisms capable of actively producing NO could have spread and evolved in spite of an increasing presence of $\mathrm{O}_{2}$ and $\mathrm{O}_{3}$. This is likely to hold true not only for terrestrial but also for aquatic life as the rise in atmospheric $\mathrm{O}_{3}$ levels will have been accompanied by corresponding increases in the amounts of $\mathrm{O}_{3}$ dissolved in the water.

\section{From a defence system to a cellular signalling pathway}

As evolution must be conservative, making use of established mechanisms that have proven advantageous when creating something new, it is little wonder that the pathway of NO production was developed further to serve other useful functions beyond the mere enhancement of survival. There is good reason to believe that the release and sensing of NO could have served as a transmitter mechanism for intra- and intercellular signalling long before specialized receptor-operated systems evolved. This is even more likely as NO does not require the help of carrier molecules in order to cross cell membranes and reach intracellular target molecules but can easily travel into cells by free diffusion ${ }^{34}$. This would also mean that a cellular signalling system between cells could have developed before the existence of cellular receptors.

Mutants lacking a NO-forming activity might have profited from being in close vicinity to NO-generating cells by sharing their microenvironmental NO shield, thus allowing for an increased resistance against the deleterious pollutant ozone. Thus, mutants of cells that were easily attracted by NO or a degradation product of NO might have possessed a kind of intracellular 'receptor' and the interaction of this receptor with NO must have produced a functional change in the cell. (This intracellular target could have been an enzyme that was activated upon NO binding or inhibited by perhaps S-nitrosylation or interaction with iron-sulphur centres.) Furthermore, if that change had activated a membrane 'adhesion molecule' in a cell that had undergone appropriate mutation, then the two cells may have become attached. In the light of recent results, sug gesting a modulatory role of $\mathrm{NO}$ for the expression of certain glycoproteins at the surface of vascular cells ${ }^{35}$, it does not appear unlikely that NO was one of the early key molecules involved in the development of the expression of adhesion proteins favouring the attachment of neighbouring cells. If cells lacking their own NO-forming system had secreted a substrate of potential use for the generator cell, a temporary or even a permanent symbiotic relation between those cells may have evolved.

\section{When and from what did NO-producing cells evolve?}

The ability to transform $\mathrm{N}_{2}$ from an atmospheric gas into a form that can be incorporated into living organisms is basic to the continuance of life on Earth. Whereas today this process is to a large extent biologically mediated, the fixed $\mathrm{N}$ pool of the early hydrosphere and soil of the Earth was mainly formed by atmospheric chemical reactions initiated by lightning discharges and shock heating of the atmosphere by large bolide impacts ${ }^{21,36}$. Recent theories on the evolution of $\mathrm{N}$ cycling suggest that denitrification arose before aerobic respiration, whereas biological $\mathrm{N}$ fixation may have been a rather late evolutionary development that arose only after the advent of an aerobic atmosphere ${ }^{37}$.

Denitrification plays an important role in soil metabolism and is defined as the process of conversion of nitrate $\left(\mathrm{NO}_{3}{ }^{-}\right)-$ the major form of Earth's fixed nitrogen to $\mathrm{NO}$, nitrous oxide $\left(\mathrm{N}_{2} \mathrm{O}\right)$, dinitrogen $\left(\mathrm{N}_{2}\right)$ or a mixture of these gases by anaerobic respiration ${ }^{38}$. Four reductases are involved in the overall denitrification pathway. The first step, carried out by a family of nitrate reductases, involves the addition of two electrons to nitrate $\left(\mathrm{NO}_{3}^{-}\right)$to form nitrite $\left(\mathrm{NO}_{2}^{-}\right)$. Upon the actions of nitrite reductase, nitric oxide reductase and nitrous oxide reductase the sequence of gaseous products formed proceeds from $\mathrm{NO}$ through $\mathrm{N}_{2} \mathrm{O}$ to $\mathrm{N}_{2}$. Denitrification occurs at efficient rates only when $\mathrm{O}_{2}$ tension is very low. Most recently, it has been demonstrated that low levels of $\mathrm{O}_{2}$ not only competitively inhibit denitrification but lead to inhibition of expression of NO reductase in Pseudomonas stutzeri ${ }^{39}$. This finding suggests that, with the change from anaerobic to aerobic conditions, such an inhibition of expression of NO reductase (which 'removes' formed NO in denitrifying microorganisms), may have been the key event responsible for the emergence of the first prokaryotes on Earth with NOaccumulating properties.

An alternative explanation for the origin of NOS may reside in the metabolic properties of nitrifying rather than denitrifying bacteria. Nitrification is the process of oxidation of ammonia $\left(\mathrm{NH}_{4}^{+}\right)$to $\mathrm{NO}_{2}^{-}$and $\mathrm{NO}_{3}{ }^{-}$(Ref. 38). $\mathrm{NO}$ and $\mathrm{N}_{2} \mathrm{O}$ are well known gaseous products of chemoautotrophically growing cells, although the exact mechanism of their formation remains to be elucidated. It is still unclear whether NO formation in nitrifying microorganisms is attributed to reduction of $\mathrm{NO}_{2}^{-}$by the enzyme nitrite reductase when using hydroxylamine $\left(\mathrm{NH}_{2} \mathrm{OH}\right)$ as an electron donor, or whether NO is a direct product of the hydroxylamine oxidoreductase reaction ${ }^{40}$. The nitrosobacteria oxidize $\mathrm{NH}_{4}{ }^{+}$by the action of ammonia monooxygenase and hydroxylamine dehydrogenase via intermediate formation of $\mathrm{NH}_{2} \mathrm{OH}$ and nitroxyl ( $\left.\mathrm{NO}^{-} / \mathrm{HNO}\right)$, respectively. Obligate lithoautotroph Nitrosomonas bacteria are able to produce $\mathrm{NO}$ under aerobic conditions ${ }^{4 !}$ by virtue of a denitrifying activity that may be non-enzymatic in nature ${ }^{40}$. Therefore, a combination of suitable metabolic activities from either pathway (i.e. from nitrifying as well as from denitrifying organisms) eventually may have served the purpose of NO formation in eukaryotic cells.

Although the early role of NO can be justified as a direct antecedent of its roles in contemporary biology, the origin of the NO used in mammalian cells cannot. NO formation in prokaryotes proceeds via reduction of $\mathrm{NO}_{3}{ }^{-} / \mathrm{NO}_{2}{ }^{-}$or oxidation of $\mathrm{NH}_{4}{ }^{+}$, respectively, whereas $\mathrm{NO}$ in mammalian cells is derived from the oxidation of one of the terminal guanidino $\mathrm{N}$ atoms of $\mathrm{L}$ arginine. Therefore, it is possible that the biological origin of NO was originally via the mechanism of denitrification or nitrification, but that later cells were able to produce the NO used for defence or cellular signalling from $\mathrm{L}$-arginine in a more efficient or controllable way. Whether or not some prokaryotic cell lines had already developed an endogenous L-arginine-NO pathway themselves or whether this change first occurred in eukaryotic cells remains to be investigated. Interestingly, a microbial NOS has been isolated recently from a Nocardia species demonstrating that NO formation from L-arginine exists in bacteria ${ }^{42}$

The question then arises as to how eukaryotic cells may have benefited from this advantageous 'invention' of prokaryotes. In analogy to the endosymbiont hypothesis on the origin of eukaryotic organelles ${ }^{43,44}$, a symbiotic relationship between once free-living denitrifying or nitrifying bacteria and protoeukaryotic host cells may have given rise to the origin of the first NO-producing eukaryotic cells. In an 
evolutionary transition, genetic information may have been transferred from the bacterial genome of the prokaryote trapped in permanent endosymbiosis to the nuclear genome of the ancestral host cell, allowing NO generation to become an inherited property of all eukaryotic cells. Alternatively, a lateral gene transfer event between prokaryotic and eukaryotic cells may have occurred.

Interestingly, it has been shown recently that the flavin-dependent reductase domain of NOS (which transfers electrons from NADPH to the catalytic domain and thereby provides the haem with reducing equivalents required for the activation of bound $\mathrm{O}_{2}$ ) is capable of reducing cytochrome $c$ and diatomic oxygen under conditions where $\mathrm{O}_{2}$ activation is uncoupled from the metabolism of its natural substrate, L-arginine. Uncoupling may then lead to the formation of $\mathrm{O}_{2}^{-}$and $\mathrm{H}_{2} \mathrm{O}_{2}$ (Ref. 45). This reductive property of NOS may in fact represent one of the ancestral functions for which this protein was designed earlier in evolution.

NOS contains a carboxy-terminal domain with sequence similarity to NADPH cytochrome $\mathrm{P} 450$ reductase $\mathrm{e}^{46}$ and represents a unique P450-type enzyme, which contains the reductase and haem domains as part of the same polypeptide ${ }^{47}$. NOS thus appears to be the first self-sufficient mammalian P450 enzyme. The fact that there is relatively little sequence homology when compared with other classical P450 enzymes suggests that NOS has converged on using the P450 chromophore for the chemistry that it carries out on a very hydrophilic substrate, L-arginine. In this respect, NOS parallels other enzymes, such as thromboxane synthase, that have the optical properties of cytochrome P150 but are otherwise only distantly related ${ }^{48}$. Interestingly, the only other known soluble P450-type enzyme of eukaryotic cells, derived from the fungus Fusarium oxysporum and tentatively termed $\mathrm{P} 450_{\mathrm{dNIR}}$, has been described to be induced by $\mathrm{NO}_{2}^{-}$and $\mathrm{NO}_{3}{ }^{-}$ and to exhibit NO reductase activity ${ }^{49}$. Together with the recent discovery of a close resemblance of certain subunits of cytochrome oxidase to those of nitric oxide reductase and nitrous oxide reductase ${ }^{50}$, this adds to the credibility of the idea of an evolutionary link between the L-arginineNO pathway and the anaerobic denitrifying respiratory system. It would be interesting to see whether or not purified NOS might be capable of reducing $\mathrm{NO}$ to $\mathrm{N}_{2} \mathrm{O}$ or, alternatively, of oxidizing $\mathrm{NH}_{4}^{+}$to $\mathrm{NO}_{2}^{-}$, activities that would support its proposed evolutionary origin. The tools of modern molecular biology will soon provide us with clues to the phylogeny of this biochemical route. We might expect that comparative sequence analysis would reveal that the genetic information encoding for NOS shows partial homology with bacterial genomes responsible for the expression of proteins involved in nitrification, denitrification, respiration and electron-transport in general.

\section{Conclusions}

NO might well have been one of the first biological signalling molecules. If this were true, it is clear why NO plays such a fundamental role in the regulation of various cellular functions. Furthermore, it suggests that many more actions of $\mathrm{NO}$ will be discovered in the future and opens up the possibility that other components of the palaeoatmosphere might also have important bioregulatory functions. For at least three such molecules $-\mathrm{N}_{2} \mathrm{O}, \mathrm{CO}$ and $\mathrm{O}_{2}$ - transmitter or modulatory functions have been postulated recently ${ }^{51-54}$.

\section{References}

1 Moncada, S. (1992) Acta Physiol. Scand. 145, 201-227

2 Nathan, C. and Xie, Q.W. (1994) Cell 78, 915-918

3 Schmidt, H.H.H.W. and Walter, U. (1994) Cell 78, 919-925

4 Radomski, M.W., Martin, J.F and Moncada, S. (1991) Philos. Trans. R. Soc. London Ser. B 334, 129-133

5 Moore, R.C., Lalicker, C.G. and Fischer, A.G., eds (1952) Invertebrate Fossils, McGraw-Hill

6 Ottaviani, E., Paemen, L.R., Cadet, P. and Stefano, G.B. (1993) Eur. J. Pharmacol. 248, 319-324

7 Elofsson, R., Carlberg, M., Moroz, L., Nezlin, L. and Sakharov, D. (1993) NeuroReport 4, 279-282

8 Elphick, M.R., Green, I.C. and O'Shea, M. (1993) Rrain Res. 619, 344-346

9 Dow, J.A.T., Maddrell, S.H.P., Davies, S.A., Skaer, N.J.V. and Kaiser, K. (1994) Am. J. Physiol. 266, R1716-R1719

10 Martinez, A., Riveros-Moreno, V., Polak, J.M., Moncada, S. and Sesma, P. (1994) Cell Tissue Res. 275, 599-603

11 Beorlegui, C., Bodegas, M.E., Villarom, A.C., Sesma, P. and Riveros-Moreno, V. (1994) Cell Biol. Int. Rep. 18, 515

12 Li, Z.S., Furness, J.B., Young, H.M. and Campbell, G. (1992) Arch. Histol. Cytol. 55, 333-350

13 Moncada, S. and Martin, J.F. (1993) Lancet 341, 1511

14 Ribeiro, J.M.C., Hazzard, J.M.H., Nussenzveig, R.H., Champagne, D.E. and Walker, F.A. (1993) Science 260, 539-541

15 Werner-Felmayer, G., Golderer, G., Werner, E.R., Gröbner, P. and Wachter, H. (1994) Biochem. J. 304, 105-111

16 Colasanti, M., Lauro, G.M. and Venturini, G. (1995) Nature 374, 505

17 Oparin, A.I. (1924) Proiskhozdenice Zhizny, lzd. Moskovski Rabochii

18 Haldane, J.B.S. (1929) Ration. Annu. 148, $3-10$

19 Scherer, S. (1985) J. Mol. Evol. 22, 91-91

20 Rubey, W.W. (1955) Geol. Soc. Am. Spec. Paper $62,631-650$
21 Levine, J.S., Augustsson, T.R., Boughner, R.E. Natarajan, M. and Sacks, L.J. (1981) in Comets and the Origin of Life (Ponnamperuma, C., ed.), pp. 161-190, D. Reidel

22 Bada, J.L. (1991) Philos. Trans. R. Soc. London Ser. B 333, 349-358

23 Levine, J.S. (1982) J. Mol. Evol. 18, 161-172

24 Maher, K.A. and Stevenson, D.J. (1988) Nature 331, 612-614

25 Miller, S.L. and Orgel, L.E., eds (1974) The Origins of Life on Earth, Prentice Hall

26 Berkner, L.V. and Marshall, L.C. (1965) J. Atmos. Sci. 22, 225-261

27 Schopf, J.W. (1993) Science 260, 640-646

28 Ratner, N. and Walker, J.C.G. (1972) J. Atmos Sci. 29, 803-808

29 Mustafa, M.G. (1990) Free Rad. Biol. Med. 9 , 245-265

30 Levine, J.S., Haysm, P.B. and Walker, J.C.G (1979) Icarus 39, 295-309

31 Crutzen, P.J. (1970) Q. J. R. Meteorol. Soc. 96 320-325

32 Krapfenbauer, A. (1991) Rosalia Austria Centralbl. Gesamte Forstwes. 108, 129-144

33 Saran, M., Michel, C. and Bors, W. (1990) Free Rad. Res. Commun. 10, 221-226

34 Malinski, T. et al. (1993) Biochem. Biophys. Res. Commun. 193, 1076-1082

35 Kubes, P., Suzuki, M. and Granger, D.N. (1991) Proc. Natl Acad. Sci. USA 88, 4651-4655

36 Yung, Y.L. and McElroy, M.B. (1979) Science 203, 1002-1004

37 Mancinelli, R.L. and McKay, C.P. (1988) Origins Life Evol. Biosphere 18, 311-325

38 Doelle, H.W. (1975) in Bacterial Metabolism (2nd edn) (Doelle, H.W., ed.), pp. 157-206, Academic Press

39 Korner, H. (1993) Arch. Microbiol. 159, $410-416$

40 Stüven, R, Vollmer, M. and Bock, E. (1992) Arch. Microbiol. 158, 439-443

41 Hooper, A.B. and Terry, K.R. (1979) Biochim. Biophys. Acta 571, 12-20

42 Chen, Y. and Rosazza, J.P.N. (1994) Biochem. Biophys. Res. Commun. 203, 1251-1258

43 Whatley, J.M., John, P. and Whatley, F.R. (1.979) Proc. R. Soc. London Ser. B 204 165-187

44 Doolittle, W.F. (1980) Trends Biochem. Sci. 5 , 146-149

45 Mayer, B. et al. (1992) J. Cardiovasc Pharmacol. 20(Suppl.12), S54-\$56

46 Bredt, D.S. et al. (1991) Nature 351, 714-718

47 Marletta, M.A. (1993) J. Biol. Chem. 268, 12231-12234

48 Marlelta, M.A. (1994) Cell 78, 927-930

49 Shoun, H. and Tanimoto, T. (1991) J. Biol. Chem. 266, 11078-11082

50 Saraste, M. and Castresana, J. (1994) FEBS Lett. $341,1-4$

51 Verma, A., Hirschm, D.J., Glatt, C.E., Ronnett, G.V. and Snyder, S.H. (1992) Science 259, 381-384

52 Marks, G.S., Brien, J.F., Nakatsu, K. and McLaughlin, B.E. (1991) Trends Pharmacol. Sci 12, 185-188

53 Daras, C., Cantrill, R.C. and Gillman, M.A. (1983) Eur. J. Pharmacol. 89 177-178

54 Gillman, M.A. (1992) Lancet 339, 307 